\title{
Seroepidemiological survey of canine visceral leishmaniasis in a continental island of northeast Brazil
}

\author{
Investigação soroepidemiológica da leishmaniose visceral canina em uma ilha \\ continental do Nordeste do Brasil
}

\begin{abstract}
Enice Fonseca Klein ${ }^{1}$, Roseclea Chagas ${ }^{1}$, Tiago Feitosa Mota ${ }^{1}$, Jairo Torres Magalhães-Junior ${ }^{2}$, Adriano Figueiredo Monte-Alegre ${ }^{3 *}$, Daniela Farias dos Santos Laranjeira ${ }^{4}$, Stella Maria Barrouin-Melo ${ }^{5}$, Carlos Roberto Franke ${ }^{6}$

${ }^{1}$ Médica Veterinária, Laboratório de Infectologia Veterinária da Universidade Federal da Bahia (UFBA); ${ }^{2}$ Doutor em Ciência Animal nos Trópicos. Docente do Centro Multidisciplinar Campus da Barra da Universidade Federal do Oeste da Bahia; ${ }^{3}$ Doutor em Parasitologia. Docente do Departamento de Biointeração do Instituto de Ciências da Saúde da UFBA; ${ }^{4}$ Doutora em Patologia Experimental e Comparada. Docente do Curso de Medicina Veterinária da UFBA;

${ }^{5}$ Doutora em Imunologia. Docente do Curso de Medicina Veterinária da UFBA;

${ }^{6}$ Doutor em Parasitologia. Docente do Curso de Medicina Veterinária da UFBA.
\end{abstract}

\begin{abstract}
Introduction: Visceral leishmaniasis (VL) is endemic disease in the neighboring municipalities of the continental island Ilha de Maré, Salvador, Bahia, Brazil. Nevertheless, VL has not been reported in the island itself. Objective: the present study aimed to investigate the seroprevalence and clinical signs of Canine Visceral Leishmaniasis (CVL) and to identify the sand fly population present in the village of Botelho, Ilha de Maré. Methodology: sera of local dogs were tested for anti-Leishmania lgG by immunoassays (screening with TR DPP ${ }^{\mathrm{T}}$ rapid test and confirmatory with indirect ELISA, Bio-Manguinhos/Fiocruz) and an entomological survey was conducted to estimate and identify the phlebotomine fauna of the region. Results: seven out of 106 samples (6.6\%) were positive using rapid test. These positive samples were sent to the Central Laboratory of Bahia for confirmation by indirect ELISA. However, all samples presentednegative results. Nine specimens of Pressatia choti, subfamily Phlebotominae were identified, being this species frequently found in areas with cutaneous leishmaniasis transmission in Brazil. Conclusion: although this work did not confirm the presence of CVL in Ilha de Maré, new serological and entomological studies in a larger area are required for the maintenance of the epidemiological surveillance in the emphasized insular area.

Keywords: Leishmania. Pressatia choti. Phlebotomines
\end{abstract}

\begin{abstract}
Resumo
Introdução: Leishmaniose Visceral (LV) é uma doença endêmica em municípios vizinhos à llha de Maré, situada na plataforma continental do município de Salvador, Bahia, Brasil. Entretanto, casos de LV não tem sido notificados nesta Ilha. Objetivo: O presente trabalho objetivou investigar a soroprevalência e sinais clínicos de Leishmaniose Visceral Canina (LVC) e identificar a população de flebótomos presentes no povoado de Botelho, Ilha de Maré. Metodologia: soro de cães locais foram testados para IgG anti-Leishmania por imunoensaios (triagem com teste rápido TR DPP'M e confirmatório com Elisa Indireto, Bio-Manguinhos/Fiocruz) e uma investigação entomológica foi conduzida para estimar e identificar a fauna flebotomínea da região. Resultados: sete de 106 amostras $(6,6 \%)$ foram positivas usando o teste rápido. As amostras positivas foram encaminhadas ao Laboratório Central da Bahia para a confirmação por ELISA indireto. Entretanto, essas amostras apresentaram resultado negativo. Foram encontrados nove exemplares da espécie Pressatia choti, subfamília Phlebotominae, espécie frequentemente encontrada em áreas de transmissão de leishmaniose cutânea no Brasil. Conclusão: apesar deste trabalho não ter confirmado a presença de LVC na Ilha de Maré, novos inquéritos sorológicos e analises entomológicas em uma maior área são necessários para a manutenção de uma vigilância epidemiológica na região insular em destaque. Palavras-chave: Leishmania. Pressatia choti. Flebotomíneos.
\end{abstract}

\section{INTRODUCTION}

Leishmaniasis are a group of zoonotic parasitic diseases, present in many countries and known in two clinical forms: visceral and cutaneous, depending on the

Correspondente/Corresponding: *Adriano Figueiredo Monte Alegre Instituto de Ciências da Saúde, Universidade Federal da Bahia - End: Av. Miguel Calmon, s.n. Valo do Canela Salvador-BA CEP: 40110.100 - Tel: (71) 99913-7189 -E-mail: adriano.monte@ufba.br
Leishmania species involved in the infection (ALVAR et al., 2012; CONTI et al., 2016; THAKUR et al., 2018). The World Health Organization include these diseases among the main zoonosis of the present time, due to its high morbidity and mortality registered in humans(WHO, 2017).

Domestic dog is considered the main urban reservoir of visceral leishmaniasis (VL), which is caused in the Americas by Leishmania infantum, due to its high susceptibility to the parasite and intense cutaneous parasitism (SILVA et 
al., 2005; VERÇOSA et al., 2008). Canine visceral leishmaniasis (CVL) cases usually precede human cases, reinforcing our belief in its importance in the dissemination of the disease to people (ROMERO; BOELAERT, 2010).

Until the end of the 20th century, VL was considered a rural disease in Brazil (WERNECK, 2014). However, after an urbanization process in the last decade it is now considered an urban disease occurring mainly in the urban environment, more than $70 \%$ of the cases (REIS et al., 2017). Currently, it is endemic even in large cities such as Belo Horizonte, the capital of Minas Gerais state or Teresina, the capital of Piaui state (BRASIL, 2014). The rise in the number of cases is associated with an increase distribution of the vector due to its adaptation to household's intra and peridomicile and migration of human and canine populations to urban centers (PRADO et al., 2011). Moreover, there has been a rise in the disease in the coastal region, an atypical habitat of VL phlebotomine vector species (JULIÃO et al., 2014). Although the municipality of Salvador, Bahia, is not considered endemic for VL, there is a risk for this zoonosis to be introduced in the city, since VL does occur in the neighboring municipalities (Barboza et al., 2009). Similarly, the continental island called Ilha de Maré, which is administratively part of Salvador, located about $5 \mathrm{~km}$ offshore (S $\left.12^{\circ} 46^{\prime} 0^{\prime \prime} / \mathrm{W} 38^{\circ} 31^{\prime} 60^{\prime \prime}\right)$, is at risk, since it has a steady influx of people and animals, often coming from surrounding areas where the disease is endemic.

The aim of this study was to investigate the occurrence and prevalence of CVL in the village of Botelho in Ilha de Maré by means of a serological survey and clinical examination of dogs, in a search for evidence of canine exposure to L. infantum. The study also included an entomological survey for sand fly vectors of the pathogen.

\section{METHODOLOGY}

Ilha de Maré has an area of $13.79 \mathrm{~km}^{2}$, with some small villages on its coast. The climate is hot and humid, typically tropical, with an average temperature of 25.5 ${ }^{\circ} \mathrm{C}$ and rainfall around $1500 \mathrm{~mm}$ per year. The ecosystem is formed by mangroves and other vegetation with a residual Atlantic forest. The island's population is estimated to be around 6.434, formed by several villages along the coast (IBGE, 2010). The survey was performed in village of Botelho which has about 500 resident families. There are no official records of the canine population in the village. Botelho is the island's closest village to the continent and it has the largest movement of both humans and dogs between the island and the mainland. In general, the residents do not have basic sanitation and many domestic animals such as chickens, ducks, horses and dogs are present in the dwellings and/or inside houses.

The points within the village where canine blood samples were collected (sampling areas) were geo-referenced, and spread over five subareas (Figure 1).The owners of the dogs brought them voluntarily to the working points in each subarea of the village. An Informed Consent Form was signed by the owners to participate in the project. After authorization, a blood sample $(8 \mathrm{~mL})$ was collected from cephalic and/or jugular veins. All dogs underwent a physical examination searching for the presence and intensity of VL clinical signs. Information on previous preventive measures against common infectious diseases such as vaccination, deworming, use of repellent collars or topical drugs against blood-sucking ectoparasites were carefully taken during anamneses. Dogs were thoroughly inspected for skin lesions, epistaxis, abnormal growth of nails, ocular lesions, signs of weight loss, presence of lymphadenomegaly and/or splenomegaly.

All procedures were previously approved by the Animal Ethics Committee of the School of Veterinary Medicine and zootechny of the Federal University of Bahia (Protocol number 19/2011).

Figure 1-The village of Botelho and its subareas of study (1, 2, 3, 4 and 5). Ilha de Maré, Salvador, Bahia, Brazil.

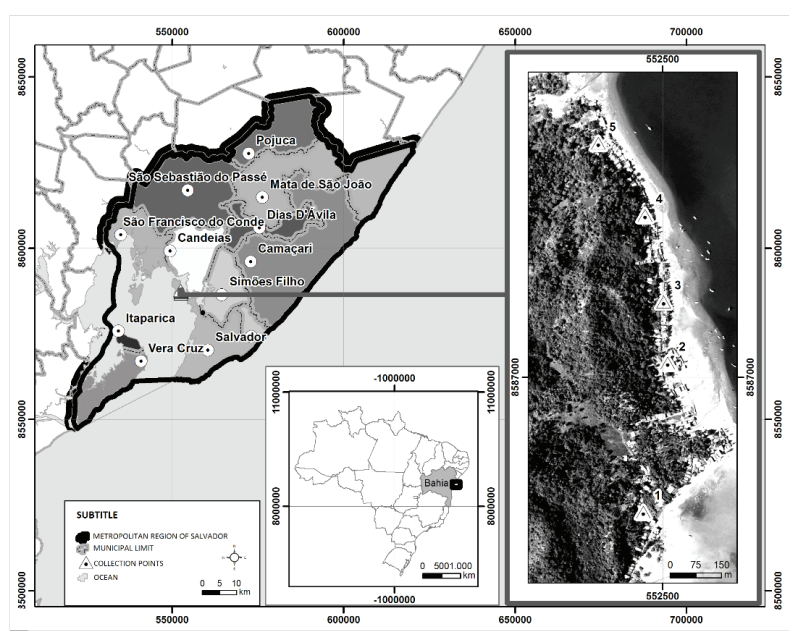

Source: authors' collection.

Blood samples from 106 animals, distributed in five working areas within the village, were refrigerated and sent to the Laboratory of Veterinary Infectology (LIVE) in the Federal University of Bahia (UFBA). In the laboratory, the samples were centrifuged and the sera were stored in labeled $1.5 \mathrm{~mL}$ microtubes (Eppendorf) at $-20^{\circ} \mathrm{C}$.

The canine immunochromatographic rapid test (TR DPP ${ }^{T M}$ Canine Visceral Leishmaniasis - Kits Bio-Manguinhos/FIOCRUZ) was performed in the laboratory to detect CVL. All positive samples detected by this test were sent to the Center Laboratory of Bahia (LACEN-BA) to confirm the results by indirect ELISA (Canine Leishmaniasis EIE Kit; Bio-Manguinhos/Fiocruz), following the recommendation of the Ministry of Health.

CDC light traps were installed from $6 \mathrm{pm}$ to $6 \mathrm{am}$ during three consecutive nights to capture sand flies. The collections were performed in two distinct moments: I) in September 2014 with the distribution of 10 light traps in locations prone to the existence of sand flies and II) in 
October 2014 with the distribution of 13 traps, for a total of $828 \mathrm{~h}$ of capture effort over the two sample periods. In each sample period, CDC light traps were installed near animal shelters (dogs and chickens), in areas with dense vegetation and abundant organic matter, and in areas close to water. The insects collected in the traps were put in plastic tubes with $70 \%$ alcohol and brought to the Hematophagous Insect Laboratory of the Instituto de Ciências da Saúde (ICS)/UFBA. Sand fly specimens were individually mounted on glass slides and identified, following the classification by Galati(2003).

\section{RESULTS}

Among 106 dogs that participated in the study, the majority was male (53.7\%), crossbreed (81.1\%), medium-sized (41.1\%), aged between three and four years old (30.2\% and $61.4 \%$, respectively). Among the canine samples analyzed, 7/106 (6.6\%) were positive for VL in the immunochromatographic rapid test. Five out of seven (71.5\%) positive samples were from dogs that lived in the sub-area 1, while two (28.5\%) from the sub-area 2. Among the dogs that tested positive in the DPP rapid test (7/106), three were born in llha de Maré, three had unknown origin and only one dog was from Salvador, in the continent area. However, none of the DPP positive samples was positive in the ELISA test.

The entomological capture effort with 23 traps in three consecutive nights, totaling 828 hours, resulted in the capture of nine specimens of Pressatia choti (five females and four males), a Phlebotominae species and possible VL vector(Table 1 ).

Table 1 - Number of collected Pressatia choti in September and October 2014, in all five evaluated subareas of Botelho, Ilha de Maré, Salvador, Bahia, Brazil

\begin{tabular}{l|c|c|c}
\hline \multirow{2}{*}{ Subarea } & \multicolumn{2}{|c|}{ Month } & \multirow{2}{*}{ Total } \\
\cline { 2 - 3 } \cline { 2 - 3 } & September & October & \\
\hline 1 & 4 & 4 & 8 \\
3 & 0 & 0 & 0 \\
4 & 0 & 1 & 1 \\
5 & 0 & 0 & 0 \\
\hline Total & 0 & 0 & 0 \\
\hline
\end{tabular}

Source: own authorship

During the study period on Ilha de Maré, it was possible to divulge the importance of visceral leishmaniasis for animals and humans, explaining the main forms of prevention and control of the disease, as well as what actions should be taken in case of suspicion of the disease.

\section{DISCUSSION}

Previous studies using the DPP rapid test showed that its sensitivity and specificity range from $46-98 \%$ and 68-96\%, respectively (GRIMALDI et al., 2012; SCHUBACH; FIGUEIREDO; ROMERO, 2014). According to the literature, this rapid test is specific and sensitive enough for surveillance studies and confirmation of CVL (Coura-Vital et al., 2014). However, the sensitivity of the rapid test depends on the dogs' clinical condition, and sensitivity is higher in symptomatic rather than asymptomatic dogs (GRIMALDI et al., 2012; PEIXOTO et al., 2015). In the present study, many of the examined dogs presented CVL suggestive clinical signs, such as onychogryphosis (a deformity of the nails), weight loss, alopecia (hair loss), or lymphadenomegaly (enlargement of the lymph nodes). These signs, however, are not CVL specific and may be common in other diseases such as babesiosis and ehrlichiosis (SOLANO-GALLEGO et al., 2011). DPP low specificity might happen in some areas where other endemic etiologic agents of canine infections co-occur with VL, especially Babesia spp., and other Leishmania species such as $L$. braziliensis, increasing false-positive results (FIGUEIREDO et al., 2018; LAURENTI et al., 2014).

In our study, ELISA tests, which were performed to confirm DPP positive results, were negative for all sera. This double check using two different serological tests allows the elimination of data from falsely positive dogs based on the rapid test (FRAGA et al., 2016). It was shown in a systematic review that ELISA sensitivity varied between $8 \%-100 \%$ and specificity between $60 \%-100 \%$ among the evaluated studies (PEIXOTO et al., 2015). Such variation could have happened due to differences on the antigen used for the ELISA and the fact that many studies use serological screening on the evaluated sample panel, leading to overestimation of the test's accuracy (BORJA et al., 2018; WHITING et al., 2011). Pressatia choti, the potential vector encountered, was also found in an entomological survey conducted in the rural area of a cutaneous leishmaniasis endemic area, Ilhéus, Bahia (CARVALHO et al., 2010), confirming the hypothesis of its adaptation to coastal areas. Pressatia choti is commonly identified among the most prevalent phlebotomine species in leishmaniasis endemic areas with dense vegetation. This was observed in forest areas in Pernambuco State (ANDRADE et al., 2005; BRANDÃO-FILHO et al., 1988), Atlantic forest reserves in Espirito Santo (VIRGENS et al., 2015), and Minas Gerais (SOUZA et al., 2015), or in areas of the Amazon region in Acre State (ARAUJO-PEREIRA et al., 2014).

Some authors suggest that there is indirect evidence for $P$. choti as a Leishmania spp. vector because this phlebotomine species is more common than other sand fly species in endemic areas for American cutaneous leishmaniasis (ACL) (BRANDÃO-FILHO et al., 1988). However, $P$. choti is not considered an ACL vector, thus far (SOUZA et al., 2015). In fact, in a study carried out in Amazonia Maranhense, the PCR evaluation of natural infection by Leishmania spp in captured P. choti specimens was negative, even though another species in the same area - Lutzomyia whitmani - was found to be positive (OLIVEIRA-PEREIRA et al., 2006). Similarly, in an ACL endemic area in Pernambuco, $P$. choti specimens were captured and 
microscopically examined, among other phlebotomines, and no isolates were found (ANDRADE et al., 2005).

According to the surveillance portal of the Directorate of Health Information of the Department of Health of Bahia (SESAB), cases of VL and ACL have been reported in the city of Salvador each year. However, these cases are not considered autochthonous, since people with suspected disease from other municipalities of Bahia come to Salvador in search for diagnosis and treatment. This hypothesis is reinforced by a lack of VL and ACL sand fly vector evidence in Salvador (MAGALHÃES-JUNIOR et al., 2012).

Salvador and especially llha de Maré are potential areas for leishmaniasis transmission, since they are bordered by VL endemic municipalities, such as Lauro de Freitas, Camaçari, Simões Filho and Dias D'Ávila (Figure 1) (JULIÃO et al., 2007) and have an intermittent migration of people and animals into Salvador from such endemic areas. Moreover, llha de Maré exhibits socio-environmental characteristics that favor the expansion of vectors and consequently pathogenic agents (BARBOZA et al., 2009). The villages in the island have very poor sanitation infrastructure and very low income levels. The spread of diseases transmitted by insect vectors most commonly reaches members of these communities who, in an effort to survive, often move temporarily for work in VL-endemic areas.

\section{CONCLUSION}

Dog seroreactivity was not confirmed, despite the data from clinical evaluation of the animals. The serological results reinforce the need to confirm the DPP positive results by the ELISA test, as recommended by the Ministry of Health. More studies are needed to improve rapid field diagnosis in dogs, in order to reduce the occurrence of false positive results.

In the entomological study, specimens of the sand fly species P. choti were detected in Ilha de Maré, which, while a possible vector, has not been confirmed as such. This uncertainty about vectors indicates the need for more frequent entomological surveys in the area, perhaps covering the entire island and analyzing the seasonal variations in the number these sand flies.

\section{ACKNOWLEDGEMENTS}

The authors would like to thank the staff at the Central Public Health Laboratory of Bahia for providing technical support for the diagnostic, as well the geographer Anderson Lobo for help in the elaboration of the map. This work was supported by the Bahia Research Foundation (Fundação de Amparo à Pesquisa do Estado da BahiaFAPESB - Grant no RED0016/2012).

\section{REFERENCES}

ALVAR, J. et al. Leishmaniasis worldwide and global estimates of its incidence. PLos ONE, San Francisco, v. 7, n. 5, 2012.
ANDRADE, M.S. et al. Sandfly fauna in a military training area endemic for American tegumentary leishmaniasis in the Atlantic Rain Forest region of Pernambuco, Brazil. Cad. saúde pública, Rio de Janeiro, v. 21, n. 6, p.1761-1767, 2005.

ARAUJO-PEREIRA, T. et al. Sand fly fauna (Diptera: Psychodidae: Phlebotominae) in an area of leishmaniasis transmission in the municipality of Rio Branco, state of Acre, Brazil. Parasit Vectors, London, v. 7, n.1, p. 360, 2014.

BARBOZA, D.C.P.M. et al. Inquérito epidemiológico da leishmaniose visceral canina em três distritos sanitários do Município de Salvador, Bahia, Brasil. Rev. Bras. Saúde Prod., Salvador, v.10, n. 2, p.434-447, 2009.

BORJA, L. S. et al. High accuracy of an ELISA test based in a flagella antigen of Leishmania in serodiagnosis of canine visceral leishmaniasis with potential to improve the control measures in Brazil - A Phase II study. PLos negl. trop. dis., San Francisco, v. 12, n. 10, p. e0006871, 2018.

BRANDÃO-FILHO, S.P. et al. Leishmaniose tegumentar americana em centro de treinamento militar localizado na Zona da Mata de Pernambuco, Brasil. Rev. Soc. Bras. Med. Trop., Brasília, v.31, n. 6, p.575-578, 1988.

BRASIL. Manual de vigilância e controle da leishmaniose visceral. Brasilia: Editora MS, 2014.

CARVALHO, S.M.S. et al. Diversidade de flebotomíneos no Município de Ilhéus, Bahia. Epidemiol. serv. saúde, Brasilia, v. 19, n.3, p. 239-144, 2010.

CONTI, R. V. et al. Visceral leishmaniasis epidemiologic evolution in timeframes, based on demographic changes and scientific achievements in Brazil. J. vector borne dis., Delhi, v. 53, n. 2, p. 99-104, 2016.

COURA-VITAL, W. et al. Evaluation of Change in Canine Diagnosis Protocol Adopted by the Visceral Leishmaniasis Control Program in Brazil and a New Proposal for Diagnosis. PLos ONE, San Francisco, v. 9, n. 3, 2014.

FIGUEIREDO, F.B. et al. Validation of the Dual-path Platform chromatographic immunoassay (DPP ${ }^{\circledR}$ CVL rapid test) for the serodiagnosis of canine visceral leishmaniasis. Mem. Inst. Oswaldo Cruz, Rio de Janeiro, v. 113, n. 11, p. e180260, 2018.

FRAGA, D.B.M. et al. the rapid Test Based on Leishmania infantum Chimeric $r K 28$ Protein improves the diagnosis of canine visceral leishmaniasis by reducing the detection of false-positive dogs. PLos negl. trop. dis., San Francisco, v. 10, n. p. 1-11, Jan. 2016.

GALATI, E. A. B. Morfologia e Taxonomia: morfologia, terminologia de adultos e identificação dos táxons da América. In: RANGEL, E.F.; LAIN$S O N$. $R$ (Ed.) Flebotomíneos do Brasil. Rio de Janeiro: Editora Fiocruz, 2003. p. 176.

GRIMALDI, J.G. et. al. Evaluation of a novel chromatographic immunoassay based on Dual-Path Platform technology (DPPW CVL rapid test) for the serodiagnosis of canine visceral leishmaniasis. Trans. R. Soc. Trop. Med. Hyg., London, v. 106, p. 54-59, 2012.

JULIÃO, F.S. et al. Investigação de áreas de risco como metodologia complementar ao controle da leishmaniose visceral canina. Pesqui. vet. bras., Rio de Janeiro, v. 27, n. 8, p. 319-324, 2007.

LAURENTI, M.D. et al. Comparative evaluation of the DPP ${ }^{\otimes} C V L$ rapid test for canine serodiagnosis in area of visceral leishmaniasis. Vet. parasitol., Amsterdam, v. 205, n. 3-4, p. 444-450, 2014.

MAGALHÃES-JUNIOR, J.T. et al. Primeiro relato da ocorrência de Evandromyia sallesi e evandromyia cortelezzii (diptera: psychodidae) na região metropolitana de Salvador, Bahia, Brasil. Rev. baiana de saúde pública, Salvador, v. 36, n.4, p.979-85, 2012.

OLIVEIRA-PEREIRA, Y.N. et al. Diagnóstico molecular da taxa de infecção natural de flebotomíneos (Psychodidae, Lutzomyia) por Leishmania sp. 
na Amazônia maranhense. Rev. Soc. Bras. Med. Trop., Brasília, v. 39, n. 6, p. 540-543, 2006.

PEIXOTO, H. M. et al. Serological diagnosis of canine visceral leishmaniasis in Brazil : systematic review and meta-analysis. Trop. med. int. health, Oxford, v. 20, n. 3, p. 334-352, 2015.

PRADO, P.F. DO et al. Epidemiological aspects of human and canine visceral leishmaniasis in Montes Claros, State of Minas Gerais, Brazil, between 2007 and 2009. Rev. Soc. Bras. Med. Trop., Brasília, v. 44, $n$. 5, p. 561-566, 2011.

REIS, L.L. et al. Changes in the epidemiology of visceral leishmaniasis in Brazil from 2001 to 2014. Rev. Soc. Bras. Med. Trop., Brasília, v. 50, n. 5, p. 638-645, 2017.

ROMERO, G.A.; BOELAERT, M. Control of visceral leishmaniasis in Latin America - a systematic review. PLos negl. trop. dis., San Francisco, v. 19, n. 4, p. 4:e584, 2010.

SCHUBACH E.Y.; FIGUEIREDO F.B.; ROMERO G.A. Accuracy and reproducibility of a rapid chromatographic immunoassay for the diagnosis of canine visceral leishmaniasis in Brazil. Trans. R. Soc. Trop. Med. Hyg., London, v. 108, n. 9, p.568-74, 2014.

SILVA, A.V.M.D. et al. Leishmaniasis in domestic dogs: epidemiological aspects. Cad. Saúde Pública, v. 21, n.1, p. 324-328, 2005.

SOLANO-GALLEGO, L. et al. LeishVet guidelines for the practical management of canine leishmaniosis. Parasit. Vectors, London, v. 4, n. 1, p. 86, 2011.

SOUZA C.F. et al. The phlebotomine sand flies fauna in Parque Estadual do Rio Doce, Minas Gerais, Brazil. Parasit. Vectors, London, v. 8, n.1, p.619, 2015.

THAKUR, L. et al. Atypical leishmaniasis: a global perspective with emphasis on the Indian subcontinent. PLos negl. trop. dis., San Francisco, v. 12, n. 9, p. e0006659, 2018.

VERÇOSA, B.L.A. et al. Transmission potential, skin inflammatory response, and parasitism of symptomatic and asymptomatic dogs with visceral leishmaniasis. BMC Vet Res., London, v. 4, p. 1-7, 2008.

VIRGENS T.M. et al. Sand fly fauna (Diptera: Psychodidae) from the goytacazes national forest and surrounding areas of southeastern Brazil. J. vector ecol., Santana, v. 40, n.1, p. 28-35, 2015.

WERNECK, G. L. Visceral leishmaniasis in Brazil: Rationale and concerns related to reservoir control. Revista de Saude Publica, v. 48, n. 5, $p$. 851-856, 2014.

WHITING, P.F. et al. QUADAS-2: A Revised Tool for the Quality Assessment of Diagnostic Accuracy Studies. Annals of Internal Medicine, v. 115, $n$. 8, p. 529-536, 2011.

WORLD HEALTH ORGANIZATION (WHO). Global leishmaniasis update, 2006-2015, a turning point in leishmaniasis surveillance. Wkly epidemiol. rec., Geneva, v. 92, n. 38, p. 557-572, 2017.

Submetido em: 03/12/2018

Aceito em: 02/09/2019 